\title{
Fiscal Consequences of Paying Interest on Reserves*
}

\author{
MARCO BASSETTO $†$ and TODD MESSER $\ddagger$ \\ $\dagger$ University College London; Federal Reserve Bank of Chicago \\ (m.bassetto@ucl.ac.uk) \\ $\$$ Federal Reserve Bank of Chicago \\ (todd.messer@chi.frb.org)
}

\begin{abstract}
We review the role of the central bank's balance sheet in a textbook monetary model and explore what changes if the central bank is allowed to pay interest on its liabilities. When the central bank (CB) cannot pay interest, away from the zero lower bound its (real) balance sheet is limited by the demand for money. Furthermore, if securities are not marked to market and the central bank holds its bonds to maturity, it is impossible for the CB to make losses, and it always obtains profits from being a monopoly provider of money. When the option of paying interest on liabilities is allowed, the limit on the CB's balance sheet is lifted. In this case, the CB is free to take on interest-rate risk - for example, by buying long-term securities and financing those purchases with short-term debt that pays the market interest rate. This is a risky enterprise that can lead to additional profits but also to losses. To the extent that losses exceed the profits of the monopoly operations, the CB faces two options: either it is recapitalised by Treasury or it increases its monopoly profits by raising the inflation tax.
\end{abstract}

*Submitted May 2013.

The authors are indebted to Fernando Alvarez, Gadi Barlevy, Mariacristina De Nardi, François Velde and seminar participants at the Federal Reserve Bank of Chicago for valuable suggestions. The views expressed herein are those of the authors and not necessarily those of the Federal Reserve Bank of Chicago or the Federal Reserve System. Marco Bassetto acknowledges support from the Centre for Macroeconomics at LSE.

Keywords: interest-rate risk, quantitative easing, monetary-fiscal interaction, excess reserves, central bank.

JEL classification numbers: E52, E58, E61, E63, H63.

(C) 2013 The Authors

Fiscal Studies (C) 2013 Institute for Fiscal Studies. Published by John Wiley \& Sons Ltd, 9600 Garsington Road, Oxford, OX4 2DQ, UK, and 350 Main Street, Malden, MA 02148, USA. 


\section{Policy points}

- When money supply is constantly increasing to accommodate growth and/or inflation, the portfolio of assets owned by a central bank is not needed to back the value of its liabilities.

- The ability to pay interest on bank reserves allows a central bank to leverage its assets and dramatically increases its capacity to take fiscal risk, which ultimately spills over to the budget constraint of the fiscal authorities.

- When fiscal and monetary authorities have independent objectives, the fiscal consequences of the central bank's asset-management choices may generate conflict and call into question its independence.

- The Federal Reserve policy of quantitative easing currently undoes at least a third of the hedge against interest-rate movements stemming from issuance of long-term debt by Treasury.

\section{Introduction}

The financial crisis of 2008 and its aftermath have brought about dramatic changes in the balance sheet of the central banks (CBs) of the largest economies in the world. Faced with the inability to wield their traditional policy instrument, which effectively hit the zero lower bound on short-term rates, CBs greatly expanded their balance sheet. While these purchases entailed a variety of assets in the immediate aftermath of 2008, they have since concentrated on bonds (particularly long-term) issued or guaranteed by the governments of their economies; as an example, Figures 1 and 2 show the case of the Federal Reserve in the United States. This expansion was financed in large part by deposits, as shown in Figure $3 .{ }^{1}$ At the beginning of the crisis, in September 2008, while the Fed funds rate was still well above zero and the Fed was not yet allowed to pay interest on reserves, these deposits were held by the US Treasury; but since then they have been largely deposits of commercial banks. Not since the Great Depression has the balance of deposits of commercial banks been so large compared with their minimum required reserves. With slight differences in timing, a very similar picture arises in the case of the European Central Bank and the Bank of England (see Figures A1 and A2 in the online appendix ${ }^{2}$ ).

Just as it took years for the expansion in the CBs' assets to take place, it is likely that years will also pass before their balance sheet returns to resemble its pre-2008 composition, with liabilities dominated by currency

${ }^{1}$ For definitions, see the online appendix (http://www.ifs.org.uk/docs/fsdec 13 bassetto\&messer appendix.pdf).

${ }^{2}$ http://www.ifs.org.uk/docs/fsdec13 bassetto\&messer appendix.pdf. 
notes. ${ }^{3}$ During this transition, excess reserves deposited by commercial banks will have to be paid the market short-term rate. If the transition is not complete by the time CBs desire to lift short-term rates from zero to contain inflationary pressures, paying interest on reserves will thus be necessary.

Our goal is not to assess the role that large-scale asset purchases played in the pursuit of monetary policy objectives; indeed, our analysis is based on a simplified model where no such role is present. Our goal is to review instead the fiscal implications of such purchases. The starting point of our analysis is Sargent and Wallace's (1981) insight that monetary and fiscal authorities are eventually forced to coordinate because they face a single, consolidated budget constraint, to which seigniorage revenues contribute. ${ }^{4} \mathrm{We}$ go beyond Sargent and Wallace by unbundling the budget constraints of the government and the CB. In a world in which the latter is simply an agency under direct control of the executive, there is no reason to distinguish

\section{FIGURE 1}

Federal Reserve assets by major category since 2007

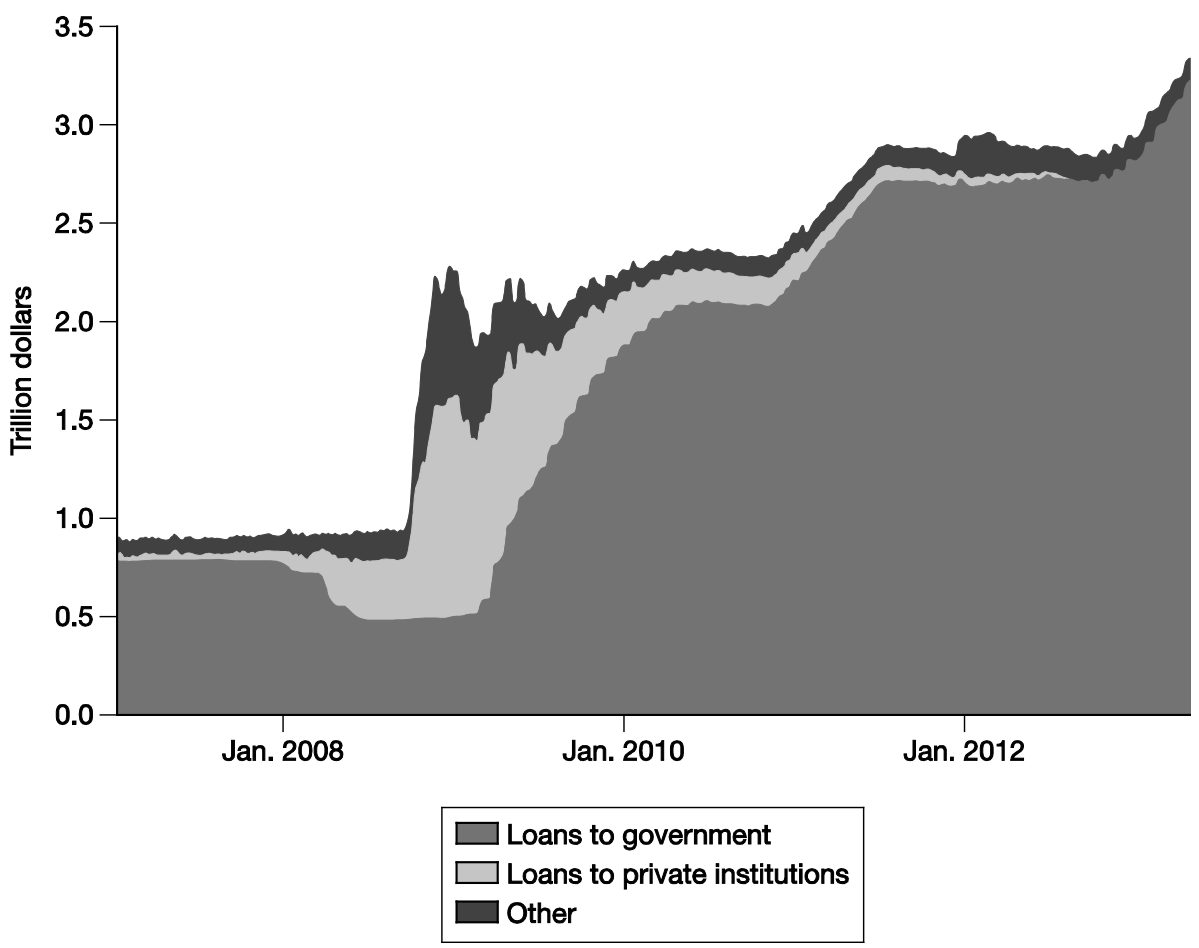

${ }^{3}$ Bank excess reserves remained elevated into the 1940 s in the aftermath of the Great Depression.

${ }^{4}$ The role of nominal debt in this connection has been explored more recently by Leeper (1991), Sims (1994), Woodford (1994), Bassetto (2002 and 2008) and Cochrane (2005), among others. Sims (2005 and 2013) has discussed in greater detail how the balance sheet of the CB affects its ability to achieve pricelevel determinacy. 
FIGURE 2

Maturity structure of Federal Reserve assets since 2007

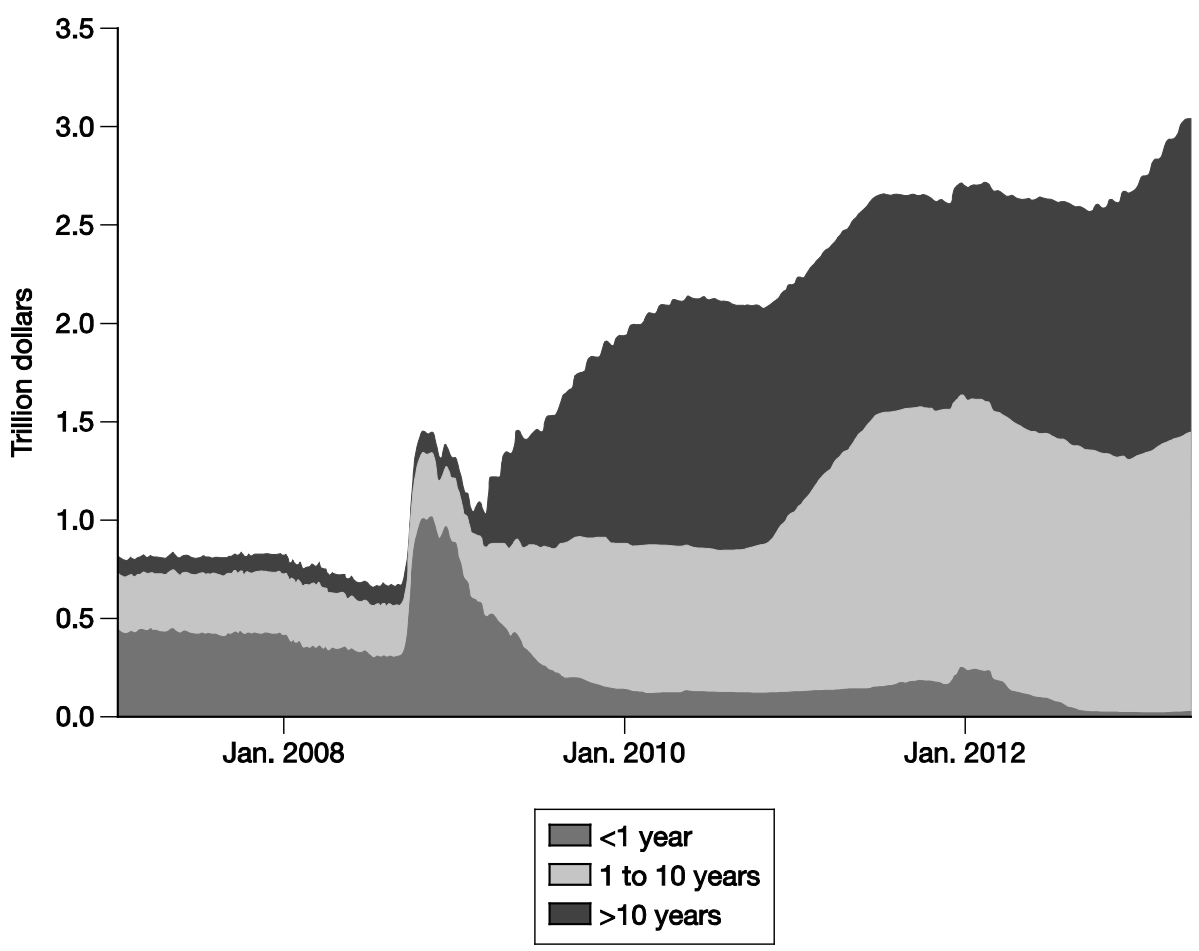

Note: This graph only includes liquidity and credit facilities, securities held outright, TALF (Term AssetBacked Securities Loan Facility), repurchase agreements and central bank liquidity swaps, for which maturity data are readily available.

between $\mathrm{CB}$ and Treasury liabilities. But things change when monetary policy is conducted by an 'independent' $\mathrm{CB}$, formally tasked with objectives, such as price and macroeconomic stability, that may conflict with the desires of fiscal authorities. In this case, it is conceivable that the magnitude of its profits and losses, as well as its transfers to fiscal authorities, may ultimately have an effect on the way fiscal-monetary coordination will occur. The CB may find it easier to concentrate on its mandate if it generates a steady stream of profits that can be transferred to Treasury. In contrast, it might find its independence under threat when it books losses, particularly in the extreme case in which these are so large as to require reverse transfers.

To analyse the implications of different asset-management policies of the $\mathrm{CB}$, we rely on a highly stylised, commonly-used model of a monetary economy. ${ }^{5}$ After displaying in Section II the linkages between the budget

${ }^{5}$ Our model is based on Lucas and Stokey (1987). 
constraints of Treasury and the central bank, confirming Sargent and Wallace (1981), we focus in Section III on the way different balance-sheet choices of the CB affect the riskiness of its position. Through a sequence of propositions, we show how increasingly aggressive portfolio-management strategies by the CB increase the risk of losses that would reduce (and, in extreme circumstances, erase or more than erase) the seigniorage transfers that can be paid to Treasury.

We identify quantitative easing, defined as purchases of long-term bonds financed with the creation of excess reserves, as a qualitative break point in the fiscal risk implied by CB policy. To better understand this break point, an analogy with an individual investor is helpful. An individual investor buying bonds using its own assets may face losses on its portfolio, but may never lose more than the entire value of its initial capital. In contrast, an investor taking a leveraged position in bonds may lose more than its capital (although, of course, such a loss may be extremely unlikely if the leverage ratio is small). Compared with the portfolio of an individual investor, the balance sheet of a central bank is more complicated, in that it involves a significant amount of liabilities (currency) that pay no interest. Moreover,

FIGURE 3

Federal Reserve liabilities by major category since 2007

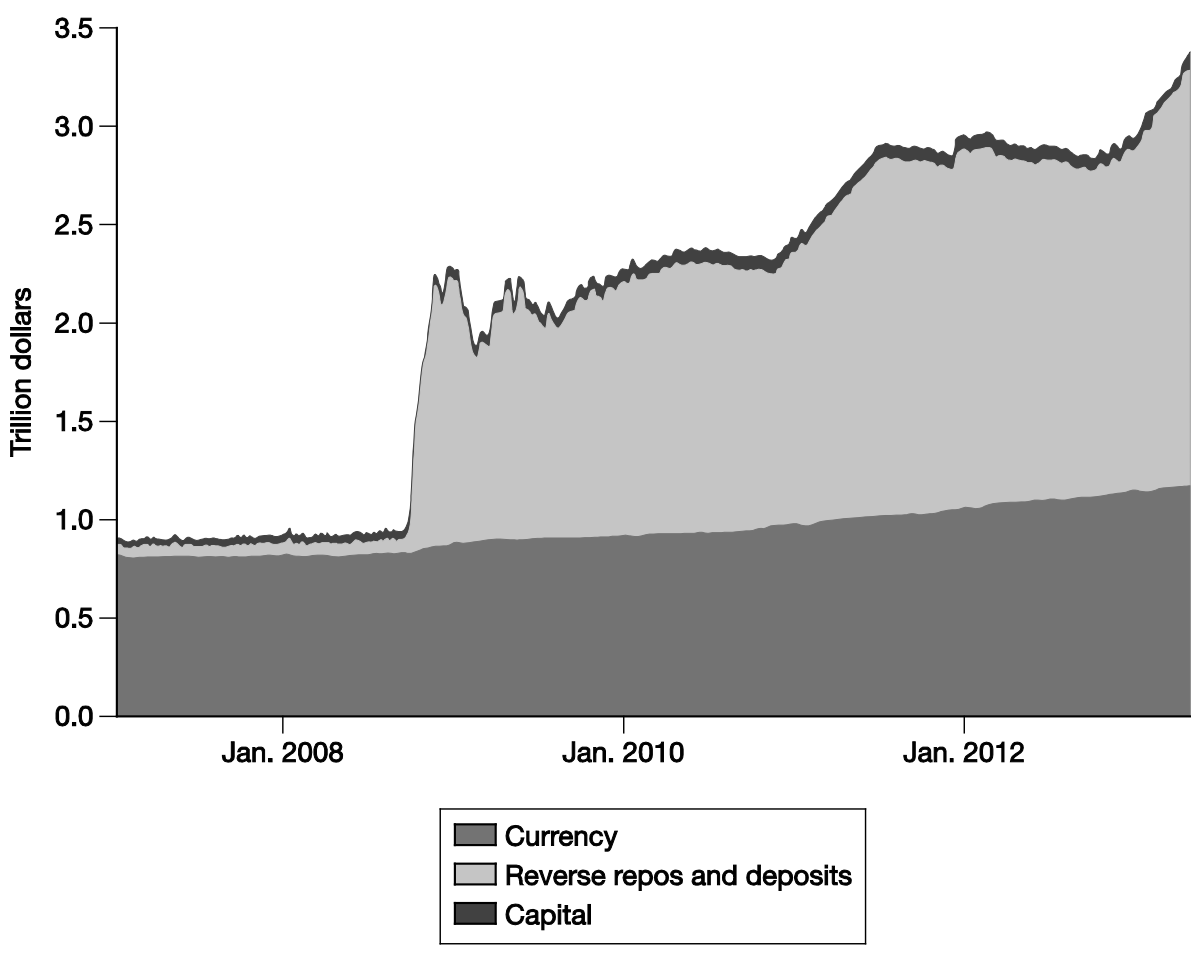


unlike the period of the gold standard, contemporary CBs do not back their currencies with assets, but rather money is irredeemable and takes value simply because of the liquidity services that it provides (money is 'fiat'). For this reason, in computing the point at which a $\mathrm{CB}$ position becomes leveraged, liabilities in the form of currency (and required reserves) can be neglected.

To complete our analysis, Section IV shows how the current positions of the US Treasury and the Federal Reserve System combine when assessing the overall exposure of fiscal authorities to interest-rate risk. Some simple computations show that the portfolio held by the monetary authorities reduces by more than a third the insurance against interest-rate movements that long-term debt offers to the taxpayers. This underscores the importance of an open debate on the division of debt-management tasks across the two agencies.

Our paper is closely related to independent work by Hall and Reis (2013), who also identify excess reserves as a force driving the $\mathrm{CB}$ to potential losses and study the implications for the conduct of monetary policy; Hall and Reis show that quantitatively the Federal Reserve and the European Central Bank are unlikely to face losses that would threaten their ability to keep prices stable in the absence of a recapitalisation. ${ }^{6}$ In our work, we discuss the budget constraints of the fiscal, as well as the monetary, authorities and emphasise the similarity in the debt instruments managed by the central bank and Treasury. We are ultimately interested in the question of how the power to take fiscal risk is allocated across the two agencies, how coordination should be managed and what institutional rules could foster proper management. Answering this question requires an explicit theory of the objectives of fiscal and monetary authorities, and the way different assetmanagement constraints affect their strategic interaction; we leave this step to future research.

\section{The set-up}

Our analysis is based on a very stylised model of an economy that features flexible prices and special assumptions about preferences, but the implications we discuss generalise to much richer environments, with more complex preferences and potentially many other frictions. We relegate the full description of the microfoundations of the model to the online appendix ${ }^{7}$ and concentrate here on the essential elements.

The economy features a continuum of private households and a government, separated into two agencies - 'Treasury' and the 'central bank' (CB). For each of these two agencies, we keep the model as simple as

\footnotetext{
${ }^{6}$ Similar projections are also contained in Carpenter et al. (2013) and Greenlaw et al. (2013).

${ }^{7}$ http://www.ifs.org.uk/docs/fsdec13 bassetto\&messer appendix.pdf. 
possible by only including their functions and the budget items that are relevant for our discussion.

Treasury issues government bonds of different maturities. We assume that there are just two maturities - one-period bonds, and consols, which promise a payment into the indefinite future. We denote by $B_{t}$ the nominal amount of one-period bonds that are issued in period $t$ and need to be repaid in period $t+1$ and by $D_{t}$ the coupons due at the beginning of period $t$ on all outstanding consols. Let $R_{t}$ be the nominal interest rate between periods $t$ and $t+1$ and $Q_{t}$ be the price of a consol in period $t$. To repay its debts, Treasury has the power to levy (lump-sum) taxes; let $T_{t}$ be their nominal amount in period $t$. We abstract from government spending.

The CB's liabilities are 'money' and 'excess reserves'. Money is interpreted here in the narrow sense of currency held by the private sector and required reserves. It has the unique feature of being monopolistically provided by the $\mathrm{CB}$ and it thus represents the source of $\mathrm{CB}$ profits. In contrast, excess reserves do not provide households any liquidity services beyond those that are also provided by short-term government debt; as a consequence, households will only hold them if they pay the same interest rate $R_{t}$ as one-period debt. We let $M_{t}$ be money that can be used in transactions in period $t$ and $X_{t}$ be the amount of excess reserves at the beginning of period $t$. On the asset side, the CB may hold government debt of either maturity. ${ }^{8}$ We assume that the $\mathrm{CB}$ cannot (or does not) sell government bonds short. Otherwise, the $\mathrm{CB}$ could circumvent a ban on paying interest on reserves simply by selling short-term Treasury bonds short. Treasury and the CB are linked by remittances (seigniorage), whose amount in period $t$ is $S_{t}$. When $S_{t}>0$, these represent distributions of profits from the $\mathrm{CB}$ to Treasury; this is the ordinary direction of transfers that we observe in the data. $S_{t}<0$ indicates a recapitalisation of the CB by Treasury.

The actions of Treasury and the $\mathrm{CB}$ are subject to their budget constraints. It is customary in macroeconomic models to lump the two constraints into one, since in practice Treasury is a residual claimant of the profits of the CB (through the seigniorage payments $S_{t}$ ) and, from a purely economic perspective, the distinction between the two agencies is superfluous. However, as we emphasised in the introduction, there are several reasons why the balance sheet of the CB may affect its independence and its ability and/or willingness to entertain alternative policy options. We thus consider the two as separate budget constraints. by

On a period-by-period basis, the budget constraint for Treasury is given

\footnotetext{
${ }^{8}$ We assume that the central bank only holds government debt. The analysis could readily be extended to the case in which the assets include privately-issued debt; in this case, in addition to interest-rate risk discussed in this paper, the central bank is also subject to credit risk.
} 


$$
B_{t-1}+D_{t-1}=\frac{B_{t}}{1+R_{t}}+Q_{t}\left(D_{t}-D_{t-1}\right)+S_{t}+T_{t}
$$

At each period $t$, the left-hand side of equation (1) represents the Treasury's repayment commitments $-B_{t-1}$ to the holders of short-term debt and a coupon $D_{t-1}$ to the holders of consols. The right-hand side represents the sources of funds - taxes from the private sector $\left(T_{t}\right)$, seigniorage transfers from the central bank to Treasury $\left(S_{t}\right)$, new issuance (or repurchase, if negative) of consols $\left(D_{t}-D_{t-1}\right.$, valued at the consol price $\left.Q_{t}\right)$ and new issuance of short-term debt $\left(B_{t}\right.$, discounted at the current short-term nominal interest rate $R_{t}$ ).

For the central bank, the budget constraint in period $t$ is

$$
M_{t}-M_{t-1}=\frac{B_{t}^{B}}{1+R_{t}}-B_{t-1}^{B}+Q_{t}\left(D_{t}^{B}-D_{t-1}^{B}\right)-D_{t-1}^{B}+S_{t}-\frac{X_{t}}{1+R_{t}}+X_{t-1} .
$$

Here, $B_{t}^{B}$ and $D_{t}^{B}$ are central bank holdings of short-term and long-term Treasury debt respectively. Equation (2) shows all the possible sources of growth in the supply of money (as defined above). The central bank must increase the money supply if it decides to acquire more short-term debt than needed to roll over existing debt; similarly, it grows the money supply if it purchases new consols with value in excess of the coupon payment on existing holdings or if it increases its remittances to Treasury. Finally, the money supply increases if the central bank uses it to repay some of its own interest-bearing liabilities (excess reserves), rather than rolling them over. A contraction in the money supply can be achieved by any combination of these factors in reverse.

The economy starts at time 0 with some initial stock of bonds, money and excess reserves, described by $\left(B_{-1}, D_{-1}, B_{-1}^{B}, D_{-1}^{B}, M_{-1}, X_{-1}\right)$.

From the terms in equation (2), it will be useful to identify the profits of the $\mathrm{CB}$, which we define in two ways, depending on whether assets are carried at their historical cost or marked to market. In period $t$, profits at historical cost are given by

$$
\Pi_{t}^{H C}:=\frac{R_{t-1}}{1+R_{t-1}}\left(B_{t-1}^{B}-X_{t-1}\right)+D_{t-1}^{B}+\left(Q_{t}-\bar{Q}_{t-1}\right)\left(D_{t-1}^{B}-D_{t}^{B}\right) I_{D_{t-1}^{B}>D_{t}^{B}}
$$

where $I_{D_{t-1}^{B}>D_{t}^{B}}$ is an indicator function that is 1 if $D_{t-1}^{B}>D_{t}^{B}$ and 0 otherwise, and $\bar{Q}_{t}$ is the average historical cost of consols held by the central bank at 
the end of period $t-1 .^{9}$ The first term of equation (3) represents net interest receipts on short-term debt instruments: the $\mathrm{CB}$ earns profits from its holdings of government debt, but makes losses when it pays interest on excess reserves. The second term represents the coupon payments on consols held at the beginning of the period. Finally, the last term, which is present only if the central bank sells long-term debt during the period, represents the realised capital gain (or loss, if negative) on the sale.

The corresponding expression for profits when assets are marked to market is ${ }^{10}$

$$
\Pi_{t}^{M M}:=\frac{R_{t-1}}{1+R_{t-1}}\left(B_{t-1}^{B}-X_{t-1}\right)+D_{t-1}^{B}+\left(Q_{t}-Q_{t-1}\right) D_{t-1}^{B} .
$$

Compared to equation (3), the first two terms are identical, but now profits (or losses) are measured taking into account both realised and unrealised capital gains.

The flow budget equations above will play an important role in our discussion of payments across different actors. Of independent interest are the present-value budget constraints, which can be computed by rolling equations (1) and (2) forward and imposing long-run balance:

$$
B_{t-1}+\left(1+Q_{t}\right) D_{t-1}=\sum_{s=t}^{\infty} \mathrm{PV}_{t}\left(S_{s}+T_{s}\right)
$$

and

$$
B_{t-1}^{B}+\left(1+Q_{t}\right) D_{t-1}^{B}-X_{t-1}+\sum_{s=t}^{\infty} \mathrm{PV}_{t}\left(M_{s}-M_{s-1}\right)=\sum_{s=t}^{\infty} \mathrm{PV}_{t}\left(S_{s}\right)
$$

where the function $\mathrm{PV}_{t}$ represents the present value computed as of time $t$; details of the PV function are provided in the online appendix. ${ }^{11}$

Equation (5) shows that the value of government debt at the beginning of period $t$ is equal to the present value of future taxes and seigniorage transfers that will be used to repay it.

In equation (6), the left-hand side represents the net value of the central bank at the beginning of period $t$. This is represented by two components. The first represents the value of holdings of government debt (which are assets for the $\mathrm{CB}$ ), net of excess reserves. The second component,

\footnotetext{
${ }^{9}$ Starting from some initial condition $\bar{Q}_{-1}, \bar{Q}_{t}$ is defined recursively as $\bar{Q}_{t}=\bar{Q}_{t-1}$ if $D_{t}^{B} \leq D_{t-1}^{B}$ and $\bar{Q}_{t}=\left(D_{t-1}^{B} / D_{t}^{B}\right) \bar{Q}_{t-1}+\left(1-D_{t-1}^{B} / D_{t}^{B}\right) Q_{t}$ otherwise.

${ }^{10}$ Since we assumed all of the $\mathrm{CB}$ liabilities to be short term, there is no issue of marking liabilities to market.

${ }^{11}$ http://www.ifs.org.uk/docs/fsdec13 bassetto\&messer appendix.pdf.
} 
represented by the infinite sum, stems from the monopoly privilege granted to the central bank to issue money, a liability that carries no interest but is still valued by the private sector for its liquidity services. This term captures the present value of monopoly profits that will accrue to the central bank from period $t$ onwards. The net value of the $\mathrm{CB}$ matches the present value of seigniorage distributed to Treasury, the right-hand side of equation (6). ${ }^{12}$

We complete the description of the economy by the following three equations, which characterise the behaviour of the private sector in each period $t$ (a full description of the microfoundations of these equations appears in the online appendix $\left.{ }^{13}\right)$ :

$$
\begin{aligned}
& \frac{M_{t}}{P_{t}}=L\left(R_{t}\right) \\
& 1=\beta_{t} \mathrm{E}_{t}\left[\frac{P_{t}}{P_{t+1}}\left(1+R_{t+1}\right)\right] \\
& Q_{t}=\frac{1}{1+R_{t}}\left\{1+\beta_{t} \mathrm{E}_{t}\left[\left(1+R_{t+1}\right) \frac{P_{t}}{P_{t+1}} Q_{t+1}\right]\right\}
\end{aligned}
$$

where $L$ is a suitable function of the underlying household preferences, described by equation (A.3) in the online appendix, $E_{t}$ represents the expected value as of time $t, P_{t}$ is the price level in period $t$ and $\beta_{t}$ is an exogenous shock to the real interest rate, ${ }^{14}$ which is the only source of extrinsic uncertainty in the model.

Equation (7) represents money demand and shows that real money balances (money divided by the price level) are a (decreasing) function of the opportunity cost of holding money, which is the nominal interest rate.

Equation (8) is a Fisher equation that relates nominal interest rates and inflation: in high-inflation environments, households require higher nominal rates to willingly hold government debt (or central bank excess reserves). ${ }^{15}$

Finally, equation (9) recursively links the price of a consol to current and future expected interest rates. In the absence of uncertainty, the equation would simplify to $Q_{t}=\left(1+Q_{t+1}\right) /\left(1+R_{t}\right)$ : the value of a consol in period $t$ would be equal to the discounted value of its dividend in period $t+1$ (which

\footnotetext{
${ }^{12}$ It is natural to think of this as dividend payments, treating Treasury as the true owner of the CB. Alternatively, it can be viewed as a tax on the CB.

${ }^{13} \mathrm{http}: / /$ www.ifs.org.uk/docs/fsdec13 bassetto\&messer_appendix.pdf.

${ }^{14}$ As commonly done in the literature (e.g. Eggertsson and Woodford, 2003), this is introduced as a preference shock. In practice, it is a short cut for a shock that affects financial intermediation and, through that channel, the desire of households to save and (in a richer model) to invest.

${ }^{15}$ Equation (8) links inflation between periods $t$ and $t+1$ to the nominal interest rate between periods $t+1$ and $t+2$. As discussed in Carlstrom and Fuerst (2001), this is a consequence of assuming the "cash-inadvance' timing. Our results would be equivalent under alternative timing assumptions in which $R_{t+1}$ is replaced by $R_{t}$.
} 
is 1) and its price in period $t+1\left(Q_{t+1}\right)$. In the presence of uncertainty, the more-complicated expression (9) takes into account the covariance between future interest rates and inflation, and it encompasses a risk premium that may make long-term rates higher than short-term rates on average.

An additional condition, which we imposed directly, states that any excess reserves held by the public must yield the same return as short-term debt. Hence, if the short-term rate $R_{t}$ is greater than zero and the CB is not allowed to pay interest on reserves, $X_{t}$ will necessarily be zero.

A (competitive) equilibrium $\boldsymbol{C}$ is thus a sequence of asset balances $\left(M_{t}, X_{t}, B_{t}, D_{t}, B_{t}^{B}, D_{t}^{B}\right)_{t=0}^{\infty}$, of taxes and seigniorage transfers $\left(T_{t}, S_{t}\right)_{t=0}^{\infty}$, of asset prices $\left(R_{t}, Q_{t}\right)_{t=0}^{\infty}$ and of present-value operators $\left(\mathrm{PV}_{t}\right)_{t=0}^{\infty}$ such that equations (1), (2), (5), (6), (7), (8), (9) and (A4) hold. ${ }^{16}$ Whenever these equations are satisfied, households find it optimal to hold money and excess reserves in amounts $M_{t}$ and $X_{t}$ respectively, as well as short-term bonds and consols in amounts $B_{t}-B_{t}^{B}$ and $D_{t}-D_{t}^{B}$ (the amount issued by Treasury, net of CB holdings).

\section{Properties of equilibria}

Having characterised the equilibrium conditions, we are now ready to study its properties. Our first step is to establish an economic equivalence proposition. This proposition formally states that, in our simple model, the timing of taxes and seigniorage transfers from the CB to Treasury is irrelevant; only their present values matter. Since taxes are non-distorting in our economy, Ricardian equivalence holds, as in Barro (1974). ${ }^{17}$ Furthermore, the dividend policy followed by the $\mathrm{CB}$ in distributing its profits to Treasury is economically irrelevant: as an example, in a period in which the CB makes large profits, it does not matter whether it immediately distributes them to Treasury or whether instead it distributes them over time, purchasing short-term Treasury debt with the retained earnings in the meantime.

Proposition 1 Let $\mathcal{C}_{1}$ be a competitive equilibrium. It is then possible to construct many other equilibria as follows:

\footnotetext{
${ }^{16}$ Equation (A4) is the expression for the present-value function, which is given in the online appendix (http://www.ifs.org.uk/docs/fsdec13 bassetto\&messer_appendix.pdf).

${ }^{17}$ The proposition would be simpler to state if the economy featured complete markets; in this case, taxes and seigniorage payments could be varied in arbitrary ways across both time and states of nature as long as their present values are unaffected. Since we do not allow arbitrary contingent contracts across agents, the proposition considers only a specific class of tax and payment shifts, that can be financed with appropriate issuance of short-term debt.
} 
1. By changing the timing of taxes:

- given some arbitrary period $t_{1}$ and some arbitrary state of nature realised in period $t_{1}$, increase (decrease) taxes in period $t_{1}$ by $\Delta T$;

- in each subsequent period $s$ up to some other arbitrary period $t_{2}>$ $t_{1}$, increase (decrease) short-term borrowing by Treasury $\left(B_{s}\right)$ by $\Delta T \prod_{v=t_{1}}^{s}\left(1+R_{v}\right)$

- decrease (increase) taxes in period $t_{2}$ by $\Delta T \prod_{v=t_{1}}^{t_{2}-1}\left(1+R_{v}\right)$.

2. By changing the timing of seigniorage remittances:

- given some arbitrary period $t_{1}$ and some arbitrary state of nature realised in period $t_{1}$, increase (decrease) seigniorage transfers in period $t_{1}\left(S_{t_{1}}\right)$ by $\Delta S$;

- in each subsequent period $s$ up to some other arbitrary period $t_{2}>$ $t_{1}$, decrease (increase) short-term borrowing by Treasury $\left(B_{s}\right)$ by $\Delta S \prod_{v=t_{1}}^{s}\left(1+R_{v}\right)$

- between periods $t_{1}$ and $t_{2}$, decrease (increase) $C B$ holdings of shortterm debt $\left(B_{s}^{B}\right)$ by $\Delta S \prod_{v=t_{1}}^{s}\left(1+R_{v}\right) ;$ alternatively, increase (decrease) excess reserves $\left(X_{s}\right)$ by the same amount;

- decrease (increase) seigniorage transfers in period $t_{2}$ by $\Delta S \prod_{v=t_{1}}^{t_{2}-1}\left(1+R_{v}\right)$.

Proof. Equations (5), (6), (7), (8), (9) and (A4) are unaffected by these changes, since they are constructed in a way that alters only the timing, but not the present value, of taxes and seigniorage revenues. Similarly, it is straightforward to verify that the debt adjustments described in the proposition are exactly those that are needed to ensure that equations (1) and (2) continue to hold. The new sequences thus satisfy all the conditions for a competitive equilibrium. QED.

The economic equivalence of Proposition 1 ignores the reality that Treasury and the CB may make decisions over time, rather than committing to their entire future strategy at time 0 , and at times they may have conflicting objectives. Specifically, it is likely that Treasury will mostly be concerned with the fiscal implications of the seigniorage transfers, while an independent central bank is typically tasked with price and macroeconomic stability. The main rationale for segregating monetary policy in an independent actor is precisely to insulate it from the temptation to resort to the printing press to inflate debt away and to raise seigniorage revenues.

When conflict is present, who controls the size and timing of seigniorage transfers may be important, and this in turn is likely to depend on the balance 
sheet of the CB. To illustrate this point with an extreme example, suppose that at time 0 the $\mathrm{CB}$ disburses to Treasury more than the value of its initial net assets, plus the entire present value of future seigniorage profits:

$$
S_{0}>B_{-1}^{B}+\left(1+Q_{0}\right) D_{-1}^{B}-X_{-1}+\sum_{s=0}^{\infty} \mathrm{PV}_{0}\left(M_{s}-M_{s-1}\right) .
$$

Using equations (2) and (6), it is easy to verify that, at least in some states of the world, this dividend policy leads the $\mathrm{CB}$ to start period 1 with net liabilities that exceed the present value of its future seigniorage profits:

$$
X_{0}-B_{0}^{B}-\left(1+Q_{1}\right) D_{0}^{B}>\sum_{s=1}^{\infty} \operatorname{PV}_{1}\left(M_{s}-M_{s-1}\right) .
$$

This situation is only sustainable if Treasury recapitalises the CB by sending some reverse transfers in period 1 or in one of the later periods. But by having to rely on transfers from Treasury, the CB may see its independence reduced, and this may affect the balance of powers between the two government agencies if their objectives conflict in the future. It is thus quite possible that such a dividend policy would generate incentives to pursue a different monetary-fiscal policy from the one that would be selected if the central bank does not disburse immediately its entire present value of its future profits, and instead retains assets and profits, disbursing the proceeds over time; in particular, a temptation might emerge to resolve the imbalance by printing extra money and thereby raising seigniorage instead.

We already observed from equation (6) that the present value of seigniorage transfers from the $\mathrm{CB}$ to Treasury arises from two distinct sources - the value of its asset portfolio and the monopoly profits on money issuance. In the discussion that follows, a special case will play a prominent role:

Definition 1 We define money to be fiat whenever monetary policy is such that $M_{s} \geq M_{s-1}$ in every period.

We call money fiat in this case because money derives value uniquely from its liquidity services, and not from the $\mathrm{CB}$ assets: the $\mathrm{CB}$ never uses its assets to redeem any money that it issued in the past. The case of fiat money is particularly relevant because it describes well the behaviour of most contemporary CBs: they increase the money supply both to accommodate real growth and to allow some inflation.

We now proceed as follows:

- We fix an arbitrary desired path for prices (and thus inflation), $P_{t}$, as well as an initial nominal interest rate $R_{0}$; in equilibrium, this determines 
all future nominal interest rates, present values and money balances (from equations (7), (8) and (A4)). ${ }^{18}$

- We then study the profits of the central bank and the evolution of its net worth under different policy scenarios that are consistent with the desired path. While $M_{t}$ and $R_{t}$ are set by the requirements of the desired path, the CB and Treasury still have freedom in setting different paths for short- and long-term debt, excess reserves, taxes and seigniorage transfers. Through a sequence of simple propositions, we illustrate how the timing and riskiness of the $\mathrm{CB}$ profits depend on its choices of asset holdings and reserves.

In particular, we will be interested in two related, but distinct, questions:

1. When will the CB be able to guarantee a positive stream of payments to Treasury all along the desired path? ${ }^{19}$

2. When will the $\mathrm{CB}$ be able to always book positive profits all along the path?

We will consider a sequence of asset-management strategies on the part of the $\mathrm{CB}$, starting from the most conservative policy, where $\mathrm{CB}$ profits are guaranteed to be positive independent of the accounting criterion, to the least restrictive one, where the $\mathrm{CB}$ is potentially exposed to unbounded losses. We will do so first for the simpler case in which the desired path features nominal interest rates that are always strictly positive. We will then expand the discussion to situations in which the short-term rate may occasionally drop to zero, in which case the distinction between the powers that the CB has with and without the ability to pay interest on reserves is blurred.

\section{1. $R_{t}>0$ always}

Bills only

We call the most conservative asset-management strategy bills only: it entails investing the entire portfolio of assets in short-term securities. ${ }^{20}$

Proposition 2 Suppose that the $C B$ is not allowed (or never chooses) to pay interest on reserves and that it invests all of its assets in short-term securities. Then its profits are always positive, whether they are measured at historical prices or marked to market.

\footnotetext{
${ }^{18}$ Fiat money will characterise a subset of these possible desired paths.

${ }^{19}$ Throughout the paper, 'positive' ('negative') means greater than or equal to (less than or equal to) 0 . Whenever a quantity is strictly greater (smaller) than 0 , we will call it 'strictly positive' ('strictly negative')

${ }^{20}$ The 'bills only' doctrine was introduced in the United States in the aftermath of the Treasury accord of 1951, which freed the Federal Reserve from pegging interest rates on government debt. For a presentation of the arguments discussed at the time, see, for example, Young and Yager (1960).
} 
Proof. With $R_{t}>0$, excess reserves will always be 0 if the CB does not pay interest on them: the private sector will find it preferable to invest in government bonds any funds that are not needed for liquidity services. Furthermore, $D_{t}^{B}=0$ in any period $t$. From equations (3) and (4), we thus obtain

$$
\Pi_{t}^{H C}=\Pi_{t}^{M M}=\frac{R_{t-1}}{1+R_{t-1}} B_{t-1}^{B} \geq 0
$$

QED.

In general, the profits from equation (12) will always be strictly positive, because the CB holds some assets on its balance sheet. However, they could be zero if the $\mathrm{CB}$ chooses (or is forced) to immediately remit to Treasury a payment equal to its assets in every period. If $\mathrm{CB}$ independence is related to its profit stream, the 'bills only' policy coupled with no excess reserves gives the best-case scenario, since the CB is guaranteed to never record losses, either at historical prices or marking its assets to market. When money is fiat, this policy can also guarantee a positive stream of seigniorage transfers, as we establish below:

Proposition 3 Suppose that the $C B$ is not allowed (or never chooses) to pay interest on reserves and that it invests all of its assets in short-term securities. In addition, suppose that money is fiat. Then the $C B$ can guarantee a positive stream of seigniorage transfers to Treasury.

Proof. In the online appendix. ${ }^{21}$

Intuitively, since its portfolio of assets is not needed to redeem money issues when money is fiat, the $\mathrm{CB}$ can simply pay to Treasury its profits from equation (12) plus the value of any new money that it issued during the period.

Buy and hold

In the strategy that we call buy and hold, the CB invests in both long- and short-term debt, but it holds all of its debt to maturity.

Proposition 4 Suppose that the $C B$ is not allowed (or never chooses) to pay interest on reserves. Suppose further that its assets are invested in both short- and long-term debt, but that the $C B$ holds long-term debt to maturity. ${ }^{22}$ Then its profits at historical prices are always positive.

\footnotetext{
${ }^{21}$ http://www.ifs.org.uk/docs/fsdec13 bassetto\&messer_appendix.pdf.

${ }^{22}$ In the case of consols, this means that the stock of consols held by the $\mathrm{CB}$ never declines in nominal terms; the $\mathrm{CB}$ uses only the coupon payments from the consols (along with maturing short-term debt) for reinvestment into new government bonds or for paying seigniorage transfers.
} 
Proof. As before, no interest payment on reserves implies $X_{t}=0$ in all periods. Furthermore, since the CB holds its debt to maturity, $D_{t}^{B} \geq D_{t-1}^{B}$ in all periods. Equation (3) then implies

$$
\Pi_{t}^{H C}=\frac{R_{t-1}}{1+R_{t-1}} B_{t-1}+D_{t-1}^{B} \geq 0 .
$$

QED.

While the value of the $\mathrm{CB}$ portfolio can now fluctuate with movements in long-term rates, the $\mathrm{CB}$ is still investing in assets that command a positive interest rate and issuing money that pays no interest rate. Under the 'buy and hold' strategy, at historical cost the CB simply books as profits the interest on short-term debt and the coupon paid by long-term debt.

We do not discuss here the profits and losses that the CB faces when its assets are marked to market, nor its ability to pay positive seigniorage transfers: this is because the implications of 'buy and hold' on these two subjects are the same as 'unlevered active trading', the strategy to which we turn next.

\section{Unlevered active trading}

Here, we do not make any assumption about the CB's portfolio, other than imposing that it does not pay interest on reserves.

Proposition 5 Suppose that the $C B$ is not allowed (or never chooses) to pay interest on reserves. Then the $C B$ losses, whether at historical prices or marked to market, cannot exceed the value of the $C B$ portfolio in the previous period (evaluated at historical prices or marked to market, respectively).

Proof. Once again, no interest on reserves implies $X_{t}=0$. From equation (3),

$$
\begin{aligned}
\Pi_{t}^{H C} & =\frac{R_{t-1}}{1+R_{t-1}} B_{t-1}^{B}+D_{t-1}^{B}+\left(Q_{t}-\bar{Q}_{t-1}\right)\left(D_{t-1}^{B}-D_{t}^{B}\right) I_{D_{t-1}^{B}>D_{t}^{B}} \\
& \geq-\bar{Q}_{t-1} D_{t-1}^{B} \geq-B_{t-1}^{B}-\bar{Q}_{t-1} D_{t-1}^{B} .
\end{aligned}
$$

From equation (4),

$$
\begin{aligned}
\Pi_{t}^{M M} & =\frac{R_{t-1}}{1+R_{t-1}} B_{t-1}^{B}+D_{t-1}^{B}+\left(Q_{t}-Q_{t-1}\right) D_{t-1}^{B} \\
& \geq-Q_{t-1} D_{t-1}^{B} \geq-B_{t-1}^{B}-Q_{t-1} D_{t-1}^{B} .
\end{aligned}
$$


QED.

When the CB invests in long-term securities, movements in long-term interest rates affect the value of its portfolio. Under 'buy and hold', these changes are reflected in the CB's accounting only if it marks its assets to market, while active trading may lead the $\mathrm{CB}$ to realise its losses and thus book them even if it values its assets at historical cost.

In either case, the CB can do no worse than losing all of its investments, which would happen in the extreme circumstance in which all of its assets are long term and the long-term interest rate becomes so large that $Q_{t}$ becomes close to zero. ${ }^{23}$ Not surprisingly, in the case of fiat money, when assets are not needed to redeem previously-issued money, such a loss would not threaten the CB's ability to pay positive seigniorage transfers, as the following proposition formally states:

Proposition 6 Suppose that the $C B$ is not allowed (or never chooses) to pay interest on reserves and that money is fiat. Then the $C B$ can guarantee a positive stream of seigniorage transfers to Treasury.

Proof. In the online appendix. ${ }^{24}$

Even though under fiat money the $\mathrm{CB}$ can arrange its payments to Treasury so as to never need a reverse transfer (a 'bailout'), the potential loss of value of its portfolio will still translate into a smaller present value of seigniorage transfers to Treasury (equation (6)); this risk may be undesirable to the fiscal authorities.

\section{Quantitative easing}

In our final step, we consider the case in which the $\mathrm{CB}$ issues interestbearing reserves. To the extent that these reserves are invested in short-term government debt, this policy has no effect: the CB buys a debt instrument that promises to pay $\$ 1$ in the subsequent period and finances the purchase by issuing a promise to deliver the same amount. ${ }^{25}$ But when the CB uses excess reserves to finance purchases of long-term debt, it is effectively taking a levered bet on long-term interest rates. Because of its leverage, the $\mathrm{CB}$ can no longer guarantee that the value of its portfolio will remain positive, independent of movements in long-term rates. If the $\mathrm{CB}$ position is sufficiently large, the losses from this bet will thus need to be covered with

\footnotetext{
${ }^{23}$ To be precise, even in this extreme circumstance the $\mathrm{CB}$ would still have positive assets left, from the coupon payment $D_{t-1}^{B}$.

${ }^{24} \mathrm{http} / / /$ www.ifs.org.uk/docs/fsdec13 bassetto\&messer appendix.pdf.

${ }^{25}$ In practice, excess reserves held by banks at the CB are overnight loans, while government debt is of longer maturity. At the height of a financial crisis, this difference may be important. For the fiscal implications considered here, a CB policy of purchasing short-term debt (e.g. of a three-month maturity) by issuing overnight reserves will still carry very low interest-rate risk.
} 
profits from the monopoly over the issuance of money or, in extreme circumstances in which not even those are sufficient, with transfers from Treasury. This intuition is formalised in the following proposition:

Proposition 7 Suppose that the $C B$ is allowed to pay interest on reserves and that the path of future long-term interest rates is uncertain. Then the $C B$ is free to choose policies that entail the risk of arbitrarily large losses. Some of these trading strategies will require transfers from Treasury to the $C B$ to keep inflation at the preset desired path.

Proof. In the online appendix. ${ }^{26}$

In our highly stylised model, where there is no cost of raising taxes, fiscal losses (whether incurred by the $\mathrm{CB}$ or by Treasury) carry no welfare consequences. This is no longer the case in environments where taxes are distortionary. Long-term debt will be particularly helpful if strains on the government budget are associated with higher long-term interest rates, a likely event in practice. Lustig, Sleet and Yeltekin (2008) study the case of distortionary taxes in detail and formally prove that the maturity structure that minimises expected distortions arising from taxes and inflation involves issuing only long-term debt. In this case, expected tax distortions increase if the $\mathrm{CB}$ engages in maturity transformation by replacing long-term debt issued by Treasury with short-term obligations of its own.

The fact that the $\mathrm{CB}$ can take risks large enough to require a recapitalisation does not mean that it will do so. As an example, Carpenter et al. (2013) and Greenlaw et al. (2013) compute some projections of the balance sheet of the Federal Reserve; under adverse scenarios, they establish that these could lead to losses according to the accounting developed here, ${ }^{27}$ but these losses would be very minor compared with the present value of seigniorage revenues going forward.

In Proposition 7, as well as in all previous propositions, we kept the stochastic process for inflation, nominal interest rates and money fixed. Because of this assumption, the CB profits and losses only had fiscal implications, affecting the size (and, in extreme cases, the sign) of seigniorage transfers to Treasury, and from there would spill over to taxes. But inflation, (nominal) interest rates and the money supply are under $\mathrm{CB}$ control. This suggests that a CB facing losses always has an alternative resorting to the printing press. To better understand this alternative, suppose that a CB starts period $t$ in a situation such that, at the desired path of

\footnotetext{
${ }^{26} \mathrm{http} / / /$ www.ifs.org.uk/docs/fsdec13 bassetto\&messer_appendix.pdf.

${ }^{27}$ What is called 'losses' in this paper is called a 'deferred asset' in Carpenter et al. (2013) and Greenlaw et al. (2013). This is consistent with a view that seigniorage payments are not profits distributed to Treasury, but rather a tax paid by the Federal Reserve. According to this interpretation, current losses could be used to reduce future seigniorage payments, and thus future tax liabilities, thereby resulting in a 'deferred asset'.
} 
inflation, nominal interest rates and money balances, the left-hand side of equation (6) is negative, which would require (sooner or later) a transfer from Treasury. The CB liabilities are made of two items, both of which can be discharged with no need of transfers from Treasury, provided the CB is willing to let money grow sufficiently fast and suffer the inflationary consequences:

- Promises to decrease the money supply (when $M_{s}<M_{s-1}$ ) can be avoided simply by never repurchasing previously-issued money, but rather by choosing an increasing path for the money supply.

- Excess reserves $X_{t}$ are simply a promise to deliver money, so they can be discharged by increasing the money supply by $X_{t}$ in period $t$ (in equation (6), this will generate a corresponding increase in the profits from the monopoly issuance of money).

\section{The zero lower bound}

Propositions 2-6 rely on the fact that excess reserves are necessarily zero unless the $\mathrm{CB}$ pays interest on them. However, whenever the nominal interest rate $R_{t}$ is at zero, this is no longer the case: the distinction between paying and not paying interest on excess reserves is lost. This has effectively been the case in the last few years.

The following proposition shows that excess reserves cannot cause losses on the CB balance sheet, whenever they are invested according to the "bills only' doctrine. This result is intuitive: any excess reserves are matched by assets of the same maturity, and hence no loss can arise from their issuance. The only qualification that is required for the case in which $R_{t}$ may hit zero is that the CB should never distribute transfers to Treasury in such an amount that it would lead its portfolio of assets to have negative value. ${ }^{28}$

Proposition 8 Suppose that the $C B$ invests all of its assets in short-term securities and that its dividend policy is such that $B_{t}-X_{t} \geq 0$ always. Then its profits are always positive, whether they are measured at historical prices or marked to market. When money is fiat and the $C B$ starts from an initial portfolio of positive value, this policy can be achieved while paying positive transfers in every period, $S_{t} \geq 0$.

Proof. After imposing $D_{t}^{B}=0$, equations (3) and (4) imply

$$
\Pi_{t}^{H C}=\Pi_{t}^{M M}=\frac{R_{t-1}}{1+R_{t-1}}\left(B_{t-1}^{B}-X_{t-1}\right)
$$

\footnotetext{
${ }^{28}$ In the case of $R_{t}>0$, this was guaranteed, since we necessarily had $X_{t}=0$.
} 
which is positive whenever $B_{t-1}^{B}-X_{t-1}$ is positive. If the CB starts from an initial condition $B_{-1}-X_{-1} \geq 0$ and the money supply is an increasing sequence (money is fiat), equation (2) implies that the CB can set $S_{t}=$ $M_{t}-M_{t-1}+B_{t-1}^{B}-X_{t-1} \geq 0$ and still retain a portfolio of zero value $\left(B_{t}^{B}=X_{t}\right)$ from period 0 onwards. QED.

While the 'bills only' doctrine ensures the $\mathrm{CB}$ against losses on its balance sheet, it also makes monetary policy particularly ineffective when short-term nominal interest rates are zero, since it is unlikely that swapping Treasury short-term liabilities for CB short-term liabilities would have any effect.

When the CB buys long-term debt, it is straightforward to verify that Propositions 4-6 continue to be true if the CB limits its creations of excess reserves to the amount of short-term bills in its portfolio. Further quantitative easing beyond this value involves taking leveraged interest-rate risk, and may cause losses that would need to be repaid with profits from money issuance and/or transfers from Treasury, even if the risk is originally taken at a time in which short-term rates are zero.

\section{A look at interest-rate risk under current policy in the United States}

The main goal of our paper has been to illustrate the ways in which specific rules of conduct imposed on the central bank may limit its ability to take fiscal risk. In this section, we illustrate the importance of such limits by showing how the assets and liabilities currently held by the Federal Reserve System alter the consolidated government's exposure to interest-rate risk. While other authors have analysed the Fed's portfolio and interest-rate scenarios in more detail, ${ }^{29}$ we are not aware of studies that have linked the Fed's interest-rate risk exposure to that of Treasury to obtain a global picture of how monetary policy is affecting the fiscal authorities' exposure to interest-rate risk.

We will compute an approximate measure of the duration of the portfolio of marketable securities issued by Treasury before taking into account the offsetting effect of the System Open-Market Account (SOMA) held by the Federal Reserve System, and see how it changes after this is incorporated.

We use the Monthly Statement of Public Debt ${ }^{30}$ to compute a schedule of payments due from Treasury on marketable debt held by the public. ${ }^{31} \mathrm{We}$

\footnotetext{
${ }^{29}$ See Carpenter et al. (2013), Greenlaw et al. (2013) and Hall and Reis (2013).

${ }^{30} \mathrm{We}$ rely on the August 2013 issue, available at http://www.treasurydirect.gov/govt/reports/pd/mspd/ 2013/2013 aug.htm. 
compute the present value of this debt relying on the yield curve produced according to the method of Gürkaynak, Sack and Wright (2007), which yields $\$ 11.7$ trillion. ${ }^{32}$ Based on these data, we obtain a duration of approximately 4.5 years for the Treasury liabilities; this implies that an increase of 10 basis points of interest rates across the entire yield curve would reduce the present value of Treasury's marketable securities held by the public by approximately $\$ 52$ billion. ${ }^{33}$

Next, we compute the effects of the Fed's assets and liabilities. We obtain the Fed's SOMA portfolio from the data published by the Federal Reserve Bank of New York. ${ }^{34}$ For Treasury and agency debt, we aggregate payments at the yearly level as done in the computation of the Treasury's marketable debt, and we use the same term structure. ${ }^{35}$ Computing the present value and duration of mortgage-backed securities is significantly more complicated, due to the prepayment risk. ${ }^{36}$ Furthermore, duration is not as reliable a measure of interest-rate risk of these securities, because the prepayment option makes their value an extremely non-linear function of interest rates. We thus value these securities at par, and we choose an extremely conservative duration of 2 years; any larger number would magnify the effect of the Fed's SOMA portfolio on the duration of the Fed/Treasury consolidated portfolio. With these inputs, the Fed's SOMA holdings ${ }^{37}$ have a present value of $\$ 3.5$ trillion $^{38}$ and a duration of 5.4 years. On the liability side ${ }^{39}$ the two large items are currency in circulation and reserve balances. Assuming that the Fed will continue to pursue a policy of fiat money (as

\footnotetext{
${ }^{31}$ For simplicity, we aggregate these payments by year, assuming that all remaining payments due in 2013 are due immediately, all 2014 payments are due in exactly 1 year, and so on. We also abstract from Treasury Inflation-Protected Securities (TIPS), where a distinction would need to be made between increases in inflation and real rates; these securities are a small fraction of the total and have little effect on our conclusions. Finally, we assume that all Treasury bills are due immediately. This slightly biases downwards our measure of duration, which is a conservative choice for our exercise: a higher duration would (slightly) increase the effect of the Fed SOMA portfolio on the overall duration of government debt.

${ }^{32} \mathrm{We}$ use data as of 4 September 2013, available at http://www.federalreserve.gov/pubs/feds/2006/ 200628/200628abs.html.

${ }^{33}$ This drop in value is a measure of the interest savings that Treasury would reap by not having to roll over debt at the new, higher rates.

${ }^{34} \mathrm{We}$ use holdings as of 4 September 2013 , available at http://newyorkfed.org/markets/soma/ sysopen_accholdings.html.

${ }^{35}$ Using the term structure of Treasury securities for agency debt neglects the interest-rate spread between the two; this is not of major concern since the spread is currently small and the amount of agency debt held by the Fed is also a small fraction of its overall portfolio.

${ }^{36}$ For a discussion, see Mattey (2000).

${ }^{37}$ Once again, we exclude TIPS from the computation.

${ }^{38}$ This number is higher than the par value reported by the Federal Reserve Bank of New York, which does not take into account unrealised capital gains.

${ }^{39}$ We obtain liabilities from the Federal Reserve Statistical Release H.4.1, available from the Board of Governors of the Federal Reserve System at http://www.federalreserve.gov/releases/h41/; we use data from the release of 5 September 2013.
} 
defined in Section III), currency in circulation does not have to be repurchased. We thus only count $\$ 2.3$ trillion of reserves held by banks; these are overnight loans to the banking sector and thus have zero duration. Since the Fed holds long-term assets partly financed by short-term liabilities, taking into account this leverage increases the interest-rate risk measured by duration: the duration of the combined portfolio is about 15.7 years. An increase of 10 basis points in interest rates reduces the value of assets held by the Fed, net of liabilities, by about $\$ 19$ billion.

The Fed's current exposure is thus not large compared with the present value of its current and future income from net interest payments year after year: in 2012 alone, net income was over $\$ 90$ billion. ${ }^{40}$ At the same time, the Fed's exposure is significant compared with Treasury's: in the event of a 10basis-point increase in interest rates, the Fed's losses would offset more than a third of the Treasury's gains. ${ }^{41}$ In terms of duration, accounting for the Fed's position reduces the duration of government debt from 4.5 to 3.2 years: a larger fraction of debt needs to be rolled over frequently, with a corresponding additional burden should interest rates increase.

It is worth noting that it would be incorrect to simply assume that the duration of government debt would be 1.3 years longer without the policy of quantitative easing pursued by the Federal Reserve System. This is because Treasury might have reacted to this policy by deliberately issuing longerterm debt. ${ }^{42}$ Nonetheless, these numbers show that quantitative easing has a measurable impact on the interest-rate risk exposure faced by taxpayers. Moreover, if quantitative easing is undone by the actions of fiscal authorities, it becomes even more important to study the political mechanisms by which the distribution of gains and losses across two agents that ultimately share the same budget constraint has an effect on the economy.

\section{Conclusion}

We have analysed simple conditions under which central bank policy ensures positive profits and/or positive transfers to Treasury. We did so by use of a highly stylised model, where the results are particularly transparent and easy to derive. Nonetheless, the implications apply equally well to much richer environments featuring nominal frictions, an explicit banking sector, and transaction or regulatory costs that may segment markets for government debt of different maturities. In these environments, more

\footnotetext{
${ }^{40} \mathrm{~A} 10$-basis-point interest-rate movement is small, and larger interest-rate movements would certainly lead to losses under marked-to-market accounting in some years, but it remains the case that these onetime losses are of the same order of magnitude as the net interest payments of a single year.

${ }^{41}$ Being based on duration, this computation is a reliable approximation for small changes in interest rates.

${ }^{42}$ See, for example, Sparshott (2013) 
interesting roles for monetary policy and quantitative easing emerge, which are not present in our simple set-up ${ }^{43}$ a trade-off would then emerge between the pursuit of these roles and the minimisation of fiscal risks.

To the extent that financial market imperfections warrant a role for adjusting the maturity structure of the liabilities of the central bank and Treasury, an expansion of the balance sheet of the central bank financed with excess reserves held by commercial banks is only one of many potential arrangements. As an example, on 17 September 2008, with the Fed funds target rate still at 2 per cent and while the Federal Reserve did not yet have power to pay interest on reserves (and thus to raise funds from commercial banks at that rate), the US Department of the Treasury announced a Supplementary Financing Program, ${ }^{44}$ whereby Treasury bills would be sold and the cash proceeds would be deposited at the Federal Reserve, which could in turn use the cash to buy privately-issued and mortgage-backed securities, without increasing the overall level of the monetary base. The Treasury deposits with the Federal Reserve did not earn interest; this represented an alternative funding mechanism for quantitative easing that shifted interest-rate risk from monetary to fiscal authorities. Similarly, to the extent that a policy of lowering long-term interest rates by shifting the maturity structure of government debt held by the public is desirable, this goal could be attained either by the policy of quantitative easing pursued by the Federal Reserve and the Bank of England, or by the Treasury's choice of concentrating its debt issues at the short end of the maturity structure. While the two options have similar implications for the portfolio of securities available to the private sector, they allocate fiscal risk differently between the central bank and the government. A goal of this paper is to stimulate further analysis on how the allocation of this risk is likely to affect macroeconomic outcomes, and ultimately on the optimal allocation of this risk.

\section{References}

Barro, R. J. (1974), 'Are government bonds net wealth?', Journal of Political Economy, vol. 82, pp. 1095-117.

Bassetto, M. (2002), 'A game-theoretic view of the fiscal theory of the price level', Econometrica, vol. 70, pp. 2167-95.

- (2008), 'Fiscal theory of the price level', in S. N. Durlauf and L. E. Blume (eds), The New Palgrave Dictionary of Economics, Basingstoke: Palgrave Macmillan.

Carlstrom, C. T. and Fuerst, T. S. (2001), 'Timing and real indeterminacy in monetary models', Journal of Monetary Economics, vol. 47, pp. 285-98.

\footnotetext{
${ }^{43}$ Optimal monetary policy in our stylised economy would call for the 'Friedman rule', where the CB pursues a deflationary policy by repurchasing money over time and keeping nominal interest rates at zero.

${ }^{44} \mathrm{See}$ http://www.treasury.gov/press-center/press-releases/Pages/hp1144.aspx.
} 
Carpenter, S. B., Ihrig, J. E., Klee, E. C., Quinn, D. W. and Boote, A. H. (2013), 'The Federal Reserve's balance sheet and earnings: a primer and projections', Federal Reserve Board, Finance and Economics Discussion Series 1.

Cochrane, J. H. (2005), 'Money as stock', Journal of Monetary Economics, vol. 52, pp. 50128.

Eggertsson, G. B. and Woodford, M. (2003), 'The zero bound on interest rates and optimal monetary policy', Brookings Papers on Economic Activity, vol. 2003(1), pp. 139-211.

Greenlaw, D., Hamilton, J. D., Hooper, P. and Mishkin, F. S. (2013), 'Crunch time: fiscal crises and the role of monetary policy', University of California - San Diego, mimeo (http://dss.ucsd.edu/ jhamilto/USMPF13 final.pdf).

Gürkaynak, R. S., Sack, B. and Wright, J. H. (2007), 'The U.S. Treasury yield curve: 1961 to the present', Journal of Monetary Economics, vol. 54, pp. 2291-304.

Hall, R. E. and Reis, R. (2013), 'Maintaining central-bank solvency under new-style central banking', Hoover Institution, Stanford University and Columbia University, mimeo (http://www.columbia.edu/ rr2572/papers/13-HallReis.pdf).

Leeper, E. (1991), 'Equilibria under "active" and "passive" monetary policies', Journal of Monetary Economics, vol. 27, pp. 129-47.

Lucas, Jr, R. E. and Stokey, N. L. (1987), 'Money and interest in a cash-in-advance economy', Econometrica, vol. 55, pp. 491-513.

Lustig, H., Sleet, C. and Yeltekin, Ş. (2008), 'Fiscal hedging with nominal assets', Journal of Monetary Economics, vol. 55, pp. 710-27.

Mattey, J. (2000), 'Measuring interest rate risk for mortgage-related assets', Economic Letter 01, Federal Reserve Bank of San Francisco.

Sargent, T. J. and Wallace, N. (1981), 'Some unpleasant monetarist arithmetic', Federal Reserve Bank of Minneapolis Quarterly Review, vol. 5, pp. 1-17.

Sims, C. A. (1994), 'A simple model for study of the determination of the price level and the interaction of monetary and fiscal policy', Economic Theory, vol. 4, pp. 381-99.

- (2005), 'Limits to inflation targeting', in B. S. Bernanke and M. Woodford (eds), The Inflation-Targeting Debate, National Bureau of Economic Research (NBER) Studies in Business Cycles, vol. 32, Chicago: University of Chicago Press.

- (2013), 'Paper money', American Economic Review, vol. 103, pp. 563-84.

Sparshott, J. (2013), 'U.S. Treasury considers ways to extend maturity of its debt', Wall Street Journal, 6 February (http://online.wsj.com/article/BT-CO-20130206-711894.html).

Woodford, M. (1994), 'Monetary policy and price level determinacy in a cash-in-advance economy', Economic Theory, vol. 4, pp. 345-80.

Young, R. A. and Yager, C. A. (1960), "The economics of "bills preferably", Quarterly Journal of Economics, vol. 74, pp. 341-73. 